\title{
Penerapan Hukum Pidana Penyebaran Berita Hoax Melalui Media Sosial Era Pandemi Covid-19
}

\author{
Faisal Azis Muttaqien*, Anang Dony Irawan \\ Prodi Ilmu Hukum, Fakultas Hukum, Universitas Muhammadiyah Surabaya, Indonesia \\ *Korespondensi : fslbrave@gmail.com
}

\section{Info Artikel}

Diajukan: 19-06-2021

Direview: 03-07-2021

Direvisi: 23-09-2021

Diterima: 25-09-2021

DOI: $10.18196 / \mathrm{mls} . v 2 i 4.12016$

\begin{abstract}
Abstrak
Kemajuan teknologi informasi berkembang sangat pesat, memberikan kemudahan mencari dan menemukan berbagai macam informasi, mendekatkan jarak yang jauh dan mempersingkat waktu untuk melakukan komunikasi. Selain memberikan perubahan positif kemajuan teknologi informasi juga memberikan perubahan yang negatif. Bahkan, penyebaran berita bohong atau Hoax yang ada di tengah- tengah masyarakat bisa menyebabkan kegaduhan hingga terjadi
\end{abstract} konflik. Metode pemeriksaan ini memanfaatkan standardisasi metodologi yang sah dengan memanfaatkan teknik metodologi hukum normatif, pemeriksaan yang disusun oleh penulis bermacam-macam materi yang menggunakan dengan menyelidiki dan merenungkan buku, hukum, pedoman, arsip, jurnal dan hasil eksplorasi lainnya yang terkait dengan penelitian. Seperti masa pandemi sekarang ini, sering kali ditemukan berita bohong mengenai pandemi covid-19 yang tersebar di jaringan media sosial contohnya seperti facebook, instagram, twitter, youtube dan masih banyak lagi. Penyebaran berita bohong atau Hoax mengakibatkan keraguan terhadap informasi yang diterima. Hal seperti ini bisa dimanfaatkan oleh kelompok yang tidak bertanggung jawab untuk menebarkan kebohongan dan juga kepanikan demi kepentingan tertentu. Oleh sebab itu perlu diketahui tentang tindak kejahatan pidana penyebaran berita bohong atau Hoax dan implementasinya. Dimuat pada pasal 45A ayat (1) sebagaimana yang dimaksud dalam Pasal 28 ayat 1 dan 2 Undang-Undang Nomor 19 Tahun 2016 perubahan atas Undang-Undang Nomor 11 Tahun 2008 tentang Informasi dan Transaksi Elektronik.

Kata Kunci : berita hoax, hoax covid-19, penyebaran berita bohong

\section{Pendahuluan}

Teknologi informasi berperan penting dimasa sekarang ini ataupun dimasa yang akan datang, seperti sekarang ini wabah virus corona atau covid-19 yang melanda hampir seluruh Negara di dunia dan membuat lapisan masyarakat yg ada di masing-masing Negara merasa khawatir terhadap jenis virus baru ini. Di tengah kekhawatiran yang melanda masyarakat, masih ada saja pihak-pihak yang menebarkan berita bohong atau Hoax terkait virus covid-19. Mengingat begitu besarnya pencarian informasi kesehatan tentang ciri-ciri terpapar virus ini dan informasi lainnya yang berkaitan dengan covid-19, bila tidak hati-hati seorang pembaca dapat menjadi korban berita Hoax tersebut.

Pemberitaan di Kompas.com pad bulan Agustus 2020 tahun lalu, kementrian komunikasi dan informatika (KOMINFO) telah menemukan adanya 1.016 hoax 
tentang corona virus-19 yang sudah tersiar pada 1.912 platform. Sementara itu, pendapat dari masyarakat anti fitnah Indonesia (MAFINDO) mulai JanuriSeptember tahun 2020 terdapat kurang lebih 600 berita Hoax tentang corona virus19 yang telahmereka jelaskan. ${ }^{1}$ Penyebar berita bohong atau Hoax bisa terancam hukuman pidanakurungan hingga 6 tahun penjara dan denda paling banyak Rp 1 Miliar karena telah melanggar Undang-Undang Informasi dan Transaksi Elektronik (UU ITE). Penting untuk diketahui harus ada pembeda antara Misinformasi dan Disinformasi jika dikaitkan dengan hukum.

Misinformasi adalah informasi atau berita palsu yang sudah tersiar namun orang yang membagikannya tidak menyadari bahwa perbuatannya itu salah. Kemudian ada istilah disebut dengan Disinformasi, yaitu berita yang dengan sengaja dibentuk supaya menimbulkan kerugian. ${ }^{2}$ Media sosial kini sangat digemari oleh masyarkat, dan munculnya pihak-pihak yang mengacaukan ketentraman dengan cara menyebar berita bohong atau Hoax merupakan dampak negatif dari media sosial itu sendiri contohnya seperti facebook, instagram, twitter, whatsapp, youtube dan platform lainnya yang saat ini dijadikan sebagai wadah gosip dan sumber dari penyebaran berita bohong.

Pentingnya penegakan hukum terhadap seseorang yang melakukan tindakan penyalahgunaan media sosial untuk menyebarkan fitnah dan kebencian, karena tindak kejahatan seperti itu termasuk parah apabila dipandang dari sudut pandang sosial budaya, hukum, hak asasi manusia, ekonomi pembangunan dan keamanan cyber. Perkembangan teknologi informasi yang disebut internet telah merubah cara berpikir dan berinteraksi masyarakat penggunanya. Ditandai dengan banyak macam tindak kejahatan atau modus di dalam dunia maya. Berdasarkan dari pendahuluan di atas, bisa disimpulkan permasalahan yakni : Penegakan aturan pidana terhadap penyebaran informasi bohong atau hoax dan halangan yang dialami pada proses penegakan aturan pidana.

\section{Metode Penelitian}

Metode penelitian ini memanfaatkan pendekatan hukum normatif dengan menggunakan metode pendekatan perundang-undangan. Penelitian yang ditulis oleh penulis pengumpulan bahan hukum menggunakan landasan teori dengan

\footnotetext{
${ }^{1}$ Halim, D. 6 Bulan Pandemi Covid-19: Hoaks dan Teori Konspirasi yang Memperparah Penanganan [Berita Online Kompas.com Sabtu, 5 Sep 2020 09.09 WIB], tersedia di situs: https://www.google.com/amp/s/amp.kompas.com/nasional/read/2020/09/05/090 diakses pada tanggal 20 Mei 2021

${ }^{2}$ Tawakal, I. Kenali Perbedaan Misinformasi, Disinformasi, Malinformasi dalam Berita Hoaks yang Sering Gegerkan Masyarakat [Berita Online depok.pikiran- rakyat.com 6 Feb 2020 10:33 WIB], tersedia di situs: https://www.google.com/amp/s/depok.pikiranrakyat.com/pendidikan/amp/pr- 09337507/kenali-perbedaan-misinformasi-disinformasimalinformasi-dalam-berita- hoaks-yang-sering-gegerkan-masyarakat, diakses pada tanggal 21 Mei 2021
} 
mengkaji dan mempelajari peraturan perundang-undangan, buku, dokumen, jurnal, laporan dan penelitian lain yang berkaitan dengan permasalahan yang menjadi objek penelitian.

\section{Hasil Dan Pembahasan}

\section{A. Penerapan Hukum Pidana Penyebaran Berita Hoax Melalui MediaSosial Era Pandemi Covid-19}

Pada dasarnya Undang-Undang yang mengatur mengenai informasi dan transaksi elektronik dikenal dengan Undang-Undang Nomor 11 Tahun 2008 tentang Informasi dan Transaksi Elektronik (ITE), dan sudah disahkan tepat pada 21 April 2008. Seiring dengan berjalannya waktu Undang-Undang itu telah selesai diamandemen menjadi Undang-Undang Nomor 19 Tahun 2016 tentang perubahan atas Undang-Undang Nomor 11 Tahun 2008 tentang Informasi dan Transaksi Elektronik (ITE) dan masih berlaku hingga saat ini.

Pasal yang mengatur tentang kasus penyebaran berita bohong atau Hoax bisa ditegakkan dengan Pasal 45A ayat (1) bahwa :

"Setiap Orang yang dengan sengaja dan tanpa hak menyebarkan berita bohong dan menyesatkan yang mengakibatkan kerugian konsumen dalam transaksi elektronik sebagaimana dimaksud dalam Pasal 28 ayat (1) dipidana dengan pidana penjara paling lama 6 tahun dan/atau dendan paling banyak Rp. 1.000.000.000,00 (satu miliar rupiah)'”.

Pasal 28 ayat (1) :

"Setiap Orang dengan sengaja dan tanpa hak menyebarkan berita bohong dan menyesatkan yang mengakibatkan kerugian konsumen dalam Transaksi Elektronik",4

Pasal 28 ayat (2) :

"Setiap Orang dengan sengaja dan tanpa hak menyebarkan informasi yang ditujukan untuk menimbulkan rasa kebencian atau permusuhan individu dan/atau kelompok masyarakat tertentu berdasarkan atas suku,agama, ras, dan antar golongan(SARA)". 5

Banyaknya pemberitaan bohong hoax, perundungan, ujaran kebencian, konflik sosial, perbuatan intoleransi, terorisme, radikalisme sebagai bukti bahwa

\footnotetext{
${ }^{3}$ Undang-Undang Nomor 19 Tahun 2016 tentang perubahan atas Undang-Undang Nomor 11 Tahun 2008 tentang Informasi dan Transaksi Elektronik

${ }^{4}$ Undang-Undang Nomor 11 Tahun 2008 tentang Informasi dan Transaksi Elektronik

${ }^{5}$ Ibid
} 
Pancasila dan Undang-Undang Dasar 1945 mengalami degadrasi nilai. ${ }^{6}$ Berdasarkan penulisandi atas, penulisan ini bertujuan untuk bisa memberitahukan dampak negatif apabila penyiaran berita bohong hoax tentang covid-19 ini terus terjadi. Semua elemen masyarakat khususnya rakyat Indonesia berperan sangat penting terhadap penyebaran berita Hoax covid-19 sehingga diperlukan adanya edukasi secara terus menerus dalam memilih berita informasi tentang pandemi nasional ini.

Gustav Radbruch pada I Nyoman Nurjaya menggunakan teorinya yaitu Rechtsidee bahwa aturan hukum idealnya wajib mewujudkan tujuannya atau cita hukum (rechtsidee) yaitu keadilan (Grechtmategheit), kemanfaatan (Doelmaghteit), kepastian (Rechmategheit), cita hukum (rechtsidee) dari Rudolf Stammler mempunyai fungsi menjadi penentu arah bagi tercapainya cita-cita masyarakat, sedangkan dari Gustav Radbruch menegaskan jua bahwa cita hukum (rechtsidee) nir hanya berfungsi menjadi tolak ukur yang bersifat regulatif, yaitu menguji apakah suatu aturan hukumpositif adil atau tidak, melainkan pula berfungsi menjadi dasar yang bersifat konstitutif, yaitu memilih bahwa tanpa cita hukum, hukum akan kehilanganmaknanya sebagai hukum. ${ }^{7}$

Maka dari itu upaya yang dapat mencegah berita bohong atau Hoax bisa dengan cara membiasakan diri untuk memiliki budaya literasi, hal demikian perlu dilakukan demi menghindari dampak buruk yang ada di masyarakat karena berita palsu atau hoax, kita bisa mengadopsi beberapa teknik untuk menentukan apakah berita itu hoax:

1. Mencermati siapa yang memposting berita tersebut sehingga kita tahu sumber kebenarannya, apabila berita itu berasal dari media-media yangtidak jelas maka perlu berhati-hati dalam melakukan penulisan atau mempercayainya.

2. Cara sumber lainnya untuk bisa dijadikan sebagai pembanding ketika berita mencurigakan yang kita baca, terutama pada media-media yang sudah memiliki kredibilitas tinggi atau yang sudah terpercaya.

3. Hoax juga ada yang berbentuk foto, selalu double check supaya tidak terjadi miskomunikasi.

4. Jangan ragu untuk memeriksa fakta berita tersebut, selalu waspada dengan judul yang mencolok dan provokatif.

5. Jika melihat adanya berita Hoax bisa langsung ditangani sendiri untuk menghentikan penyebaran, dengan meng-klik fitur "Report/Laporkan" jika

\footnotetext{
${ }^{6}$ Supriyono \& Irawan, A. D. (2020). Semangat Kebangkitan Nasional Untuk MenghadapiCovid-19 Dalam Konteks Pancasila dan Konstitusi. Jurnal Pendidikan Sosial Keberagaman, 7(2).

${ }^{7}$ Pawestri, A. Y. (2019). Citra Hukum dan Demokrasi dalam Sistem Penegakkan HukumLingkungan Indonesia. Jurnal Ilmiah Ilmu Hukum, 17 (2), h. 98.
} 
ditemukan di facebook, instagram, twitter, youtube.

Hoax yaitu suatu berita informasi yang dengan sengaja ditambahi atau dikurangi dari informasi yang terjadi sebenarnya, ada unsur manipulasi data atau modifikasi yang berguna untuk mendapatkan respon yang cukup banyak hingga menjadi viral. Seperti kabar pandemi covid-19 yang penyebarannya terjadi di daerah yang belum tentu pasti kebenarannya, tetapi sudah menimbulkan rasa kepanikan dan kekhawatiran bagi masyarakat sekitar. Hoax memberikan pengaruh kepada semua orang yang sudah membaca berita bohong agar percaya dengan berita tersebut seperti benar keadaanya. ${ }^{8}$

Masyarakat yang tinggal di desa sering kali mengalami kesulitan dalam memilih informasi yang sedang viral baik di lingkungan sekitar maupun di sosial media, apakah berita itu fakta atau Hoax. Oleh sebab itu pemerintah memberikan arahan dan himbauan terhadap masyarakat untuk lebih berhati-hati dalam mencari atau pun mendapat informasi. Berita hoax sudah banyak menghantui masyarakat, polisi pun mulai gencarkan patroli cyber dan mendapatkan pelaku penyebar hoax tentang corona virus-19 di Indonesia sebanyak 41 kasus pada 23 Maret 2020. ${ }^{9}$

Akibat dari penyebaran berita bohong atau Hoax, keamanan negara telah melakukan berbagai upaya untuk menangani kejahatan di dalam bidang teknologi informasi. Pihak kepolisisan berusaha melakukan penyelidikan terhadap kegiatan yang berkaitan dengan cyber serta memfungsikan laboratorium komputer forensik demi mendukung proses penyidikan kejahatan yang ada di dunia maya. Penegakkan hukum atau bisa disebut dalam bahasa inggris Law Enforcement dan Rechthandavingsebutan dalam bahasa Belanda.

Handhaving menurut Handhave Milieurecht, Handhave adalah penmantauan dan penegakan penggunaan dokumen administratif, pidana, atau perdata untuk memahami kondisi dan ketentuan hukumyang berlaku secara umum. ${ }^{10}$ Pada Pasal 28ayat (2) UU ITE masih saja menyebabkan pemahaman yang multitafsir.

Tetapi pada faktanya, pasal tersebut sudah digunakan dalam menuntaskan banyak kasus yang telah melanggar isi dari Pasal tersebut. Meski suatu undangundang itu telah dibentuk dengan menggunakan kata-kata dan istilah yang tegas, tetapi masih ada kemungkinan untuk memberikan penafsiran bahkan dapat menimbulkan keraguan. ${ }^{11}$ Namun masih saja ada pihak-pihak yang merasa memiliki kekuasaan justru memanfaatkan kesempatan itu untuk hal-hal yang merugikan

\footnotetext{
${ }^{8}$ Juditha, C. (2018). Interaksi Komunikasi Hoax di Media Sosial serta Antisipasinya. Jurnal Pekomnas, 3(1), h. 31-44.

${ }^{9}$ Wahid, A. B. "Gencarkan Patroli Siber, Polri tangani 41 Hoax soal Corona", tersedia di situs: https://news.detik.com/berita/d-4949856/gencarkan-patroli-siber- polri-tangani-41-hoax-soal-corona diakses 4 Juni 2021

${ }^{10}$ Hamzah, J. A. (2005). Penegakan Hukum Lingkungan, Sinar Grafika, Jakarta, h. 48

${ }^{11}$ Lamintang, P.A.F. \& Samosir, C.D. (2010). Delik-delik Khusus Kejahatan yangDitujukan Terhadap Hak Milik dan lain-lainHak yang Timbul dari Hak Milik, TARSITO,Bandung.
} 
orang lain. Seseorang yang ditahan tanpa didasarkan alasan yang jelas atau kesalahan dalam penulisan identitas diri, uraian singkat, serta tempat dilakukan penahanan, tidak dapat dilakukan penahanan. ${ }^{12}$

Perbuatan yang bisa dikategorikan melanggar Pasal 28 ayat (2) UU ITE yaitu, 1) Adanya pihak-pihak yang merasa dirugikan oleh perbuatan seseorang atau sekelompok orang yang berkaitan dengan unsur SARA, 2) Perbuatan tersebut memuat gambar-gambar tentang orang-orang yang disucikan dalam suatu agama yang bertentangan dengan gambar aslinya, 3) Membuat tulisan yang menjelekjelekan isi dari kitab suci suatu agama yang berbeda dengan ajaran agama tersebut atau, 4) Menyebarluaskan hal-hal yang bersifat pribadi yang bertentangan atau melanggar norma-norma atau kesopanan kesusilaan, 5) Perbuatan yang dilakukan mengandung unsur SARA dan dilakukan di media sosial. ${ }^{13}$ Penegakkan hukum yaitu suatu proses demi terwujudnya tujuan-tujuan hukum untuk menjadi kenyataan. Hukum sendiri tidak menggunakan model dari perbuatan yang sudahada, tetapi berorientasi pada terciptanya perilaku baru.

\section{B. Kasus Penyebaran Berita Hoax Covid-19 di Indonesia}

Pegawai honorer yang berada di salah satu instansi Satgas Percepatan Penanganan corona virus-19 Kalimantan barat berinisial AS (30 tahun) telah diringkus Tim Patroli Cyber Ditreskrimum Polda Kalbar. AS tertangkap karena sudah membuat postingan yang berisi informasi palsu atau Hoax di media sosial Facebook. AKBP Pratomo Satriawan menerangkan, ketika melakukan pemeriksaan Cyber pihaknya mengidentifikasi atas nama akun AS menyiarkan berita bohong tentang vaksin. Dalam postingannya AS mengetikan di kolom komentar, bahwa vaksin covid-19 yang akan disuntikkan kepada warga adalah virus yang berbahaya. "Awas itu bukan vaksin tetapi virus yang akan menghancurkan rakyat Indonesia, pertama disuntik memang tidak nampak terkena langsung virusnya, nanti jelang 4 atau 6 bulan baru kelihatan yang pernah disuntik, timbul penyakit karena virus suntikan tadi dari vaksin tadi, awas hati-hati jangan tertipu, hati-hati rakyat sebelum disuntikfikirkan sejauh-jauhnya, lebih baik jangan kita mah udah sehat kok buat apa disuntik, jangan takut dengan corona", ${ }^{14}$ tulis AS dalam kolom komentar postingan yang ada di grup Facebook Pontianak Informasi. Sebelum melakukan penangkapan dan membenarkan AS menjadi tersangka, Polda Kalimantan barat telah meminta arahan dari saksi ahli terlebih dahulu atas perbuatan yang dilakukan AS. Dalam memuat postingan di kolom komentar terkait vaksin itu AS menggunakan akun pribadi miliknya, dan

\footnotetext{
${ }^{12}$ Zakarya, I. B. dkk. (2014), Kewenangan Jaksa PenuntutUmum dalam Penahanan Tersangka Tanpa Alasan yang Jelas. Other thesis, Universitas Muhammadiyah Surabaya.

${ }^{13}$ Situmorang, F.S. dkk. (2017), Tinjauan Yuridis Terhadap Ketentuan Pasal 28ayat 2 UU informasi dan tekhnologi, Kertha Wicara, 6(5), h. 12.

${ }^{14}$ Firmansyah, T. Polisi Tangkap Penyebar Hoaks Vaksin [Berita onlineREPUBLIKA.co.id, Kamis 28 Januari 2021 20:20 WIB] tersedia di situs: https://www.google.com/amp/s/m.republika.co.id/amp/qnnbqj377, diakses pada tanggal 22 Mei 2021
} 
tulisan itu murni kalimat yang telah dibuat AS bukan kalimat saduran. Perbuatan AS telah melanggar pasal 45A ayat 1 Jo pasal 28 ayat 1 Undang-Undang Nomor 19 tahun 2016 perubahan atas Undang-Undang Nomor 11 tahun 2008 tentang Informasi dan Transaksi Elektronik (UU ITE), dan pasal 14 ayat 2 Undang-Undang Nomor 1 tahun 1946 tentang Peraturan Hukum Pidana karena telah menyebarkan berita bohong tentang vaksin covid-19.

\section{Faktor yang Menghambat Penegakan Hukum Pidana PenyebaranBerita Bohong}

Otoritas hukum pidana dapat diuraikan sebagai interaksi yang dibuat oleh otoritas pelaksanaan hukum dengan menganalisa pihak yang terkait yang telah melakukan kesalahan secara hukum. Pemeriksaan yaitu suatu proses yang diawali dari penyidikan, penuntutan, dan berakhir pada penentuan hukuman. Proses yang demikian merupakan proses peradilan pidana (Criminal Justice Process). Sasaran akhir dari penegakan hukum pidana adalah menanggulangi kejahatan dengan cara menghukum setiap orang yang telah divonis bersalah. ${ }^{15}$

\section{Faktor Hukum}

Ada banyak Undang-Undang dan pedoman tentang penyiaran berita bohong atau Hoax mulai dari KUHP dan hukum khusus yang mengaturnya materi hukum yang sering kita gunakan selama ini dan difungsikan untuk kepentingan banyak orang, dalam proses membuatnya jauh dari keterlibatan masyarakat (nir-sosiologis) tidak memperhatikan kritik dari masyarakat. Meskipun materi tersruktur dengan baik, tetapi sistem itu berlaku secara rinci dan sistematis untuk orang-orang yang tidak memiliki relasai di lingkungan para peradilan hukum. Tetapi sangat lemah bagi anggota parlemen itu sendiri, bahkan berlaku untuk pihak-pihak tertentu yang meimiliki pengaruh dalam kepentingan mereka bukan tidak mungkin untuk mendapatkan berbagai jenis kompensasi.

Tujuan dari penciptaan pemberlakuan adalah untuk permintaan dan keaslian juga berpikir tentang kemampuan. Tindak kejahatan di dunia maya merupakan kejadian yang tidak bisa dianggap remeh, tindakan itu seperti pemalsuan surat dan dokumen penting (data forgery), propaganda terorisme melalui internet (cyber terorism), merusak sistem keamanan komputer untuk mencuri, membajak hingga melumpuhkan sasaran (cracking) dan penyebaran berita bohong (hoax), untuk menjamin jaminan yang sah otoritas publik berkewajiban untuk mengelola pembelajaran yang diidentifikasi dengan penggunaan inovasi dan korespondensi.

Dengan berbagai macam masalah yang terutama diidentifikasi dengan lembaga saat ini dan berdampak pada langkah implementasi hukum tidak membuatnya lebih mudah akan tetapi membuat penanganan semakin sulit, ada berbagai hambatan yang harus segera di selesaikan pelaksanaan hukum pidana,

\footnotetext{
${ }^{15}$ Yosep, T. (2016). Advokat dan Penegakan Hukum, GENTA Press, Yogyakarta.
} 
faktor perundang-undangan atau regulasi yang belum sesuai dan belum tersistematisasi secara baik dan benar. ${ }^{16}$

Belum beraturannya regulasi yang tidak bisa sejalan dengan asas tidak multi tafsir (lex certa) perlu diterjemahkan seperti apa yang dibaca (lex stricta) pada akhirnya telah menimbulkan inflasi hukum, dimana masih terdapat begitu banyak regulasi perundang-undangan yang sudah diterbitkan namun pada hakikatnya nilai dan kualitas terus dianggap mengalami penurunan dalam kehidupan bermasya rakat. ${ }^{17}$

\section{Faktor Aparat Penegak Hukum}

Berbicara tentang aparat penegak hukum yang ada di negara Indonesia rasanya masih mengkhawatirkan, sudah bukan menjadi rahasia umum lagi kalau mafia peradilan kita sangat buruk dan para aparat penegak hukum yang menjadi peran utama atas kerusakan hukum yang ada di Indonesia. Setegas apapun materi perundang-undangan yang telah dibuat, kalau moral aparatnya sudah rusak, maka menegakkan hukum demi keadilan dan kebenaran itu bagaikan menegakkan sumbu yang sudah basah. Disisi lain aparat penegak hukum mengalami kesulitan dalam menangani kasus Cyber Crime, yang demikian di latar belakangi dengan masih banyaknya masyarakat yang belum memahami tentang teknologi informasi, serta terbatasnya sarana dan prasarana.

Dari sisi yang lain negara Indonesia masih membutuhkan aparat penegak hukum yang ahli dalam bidang Cyber, kemudian menyatukan komunitas atau organisasai yang memiliki keahlian dalam penanganan segala jenis tindak kejahatan Cyber. Tanpa adanya tenaga ahli yang benar-benar mumpuni dalam bidang seperti ini maka akan sulit menjerat penjahat-penjahat yang berkeliaran di dunia maya karena kejahatan Cyber ini locus delicti ${ }^{18}$ bisa berasal dari luar negeri (lintas negara). Untuk menangani kasus cybercrime khususnya penyebaran berita bohong diperlukan adanya tenaga ahli dari para penyidik sebagai pelaksana penegakan hukum dalam penyebaran berita hoax. Para penyidik ini tentunya memiliki dasar pendidikan yang mampu memahami dan menguasai teknik dan ilmu dasar khusus dalam bidang teknologi komputer. ${ }^{19}$.

\section{Faktor Masyarakat}

Dalam upaya untuk menanggulangi dan mengungkap kejahatan cyber ini

\footnotetext{
${ }^{16}$ Fahriza, R. (2018), Stagnansi Penegakan Hukum di Indonesia Menjadi Alarm, https://m.antaranews.com, diakses pada 9 Juni 2021

${ }^{17}$ Ibid

${ }^{18}$ Locus delicti adalah locus dalam bahas inggris artinya lokasi atau tempat, secara istilah berarti berlakunya hukum pidana yang dilihat dari segi lokasi terjadinya perbuatan pidana. Locus delicti perludiketahui untuk menentukan apakah hukum pidana indonesia berlaku terhadap perbuatan pidana tersebut atau tidak

${ }^{19}$ Sumadi, H. (2016). Kendala dalam menanggulangi tindak pidana penipuan transaksielektronik di Indonesia, https://download.portalgaruda.org/article diakses pada tanggal 10 juni 2021
} 
tidaklah mudah, pentingnya kesadaran hukum bagi masyarakat adalah hal yang sangat penting yang akan menentukan berjalannya suatu hukum di masyarakat. Apabila kesadran masyarakat terbilang cukup tinggi dalam mentaati dan menjalankanperaturan yang sudah diatur oleh hukum, maka hukum tersebut telah berlaku efektif. Kesadaran hukum masyarakat merupakan salah satu unsur pertama yang harus diperhitungkan dalam berfungsinya suatu hukum secara efektif di dalam masyarakat. ${ }^{20}$ Yang demikian berarti kesadaran hukum bagi masyarakat menjadi tolak ukur pertama dalam mematuhi proses hukum, tidak hanya didasari dengan adanya rasa takut tetapi juga karena kesadaran bahwa hukum tersebut sesuai dengan nilai-nilai yang tumbuh dalam kepatuhan hukum. Teknologi informasi dan komunikasi sudah dimanfaatkan dalam kehidupan sosial masyarakat dan juga sudah berjalan di berbagai macam sektor kehidupan, mulai dari sektor pemerintahan, perbankan, bisnis, kesehatan, pendidikan dan kehidupan pribadi masyarakat. ${ }^{21}$

\section{Simpulan}

Dasar hukum dari penyebaran berita bohong atau hoax diatur dalam UndangUndang No 19 Tahun 2016 tentang perubahan atas Undang-Undang No 11 Tahun 2008 tentang informasi dan transaksi elektronik pasal 45A ayat 1 dan pasal 28 ayat 1 dan 2, penyebaran berita palsu juga bisa dijerat dengan pasal 310, 311, 378 dan 390 KUHP. Dalam situasi pandemi seperti sekarang ini kasus penyebaran berita bohong atau hoax semakin marak terjadin peran masyarakat dalam upaya menghindari penyiaran informasi hoax bisa dengan cara melakukan penyaringan dan pemilihan informasi yang didapatkan dengan begitu masyarakat tidak tertipu kedalam informasi-informasi yang tidak sesuai dengan fakta. Karena penyiaran informasi hoax tentang pandemi covid-19 ini mempunyai dampak yg luarbiasa dan konsekuensi yang besar dalam kasusnya, membiasakan budaya literasi merupakan salah satu cara terbaik agar terhindar dari rasa takut, kekhawatiran dan kecemasan yang berlebihan terhadap berita-berita yang berkaitan dengan covid-19 baik secara online maupun offline.

\section{Daftar Pustaka}

\section{Buku}

Hamzah, J. A. (2005). Penegakan Hukum Lingkungan, Sinar Grafika, Jakarta. Lamintang, P.A.F. \& Samosir, C.D. (2010). Delik-delik Khusus Kejahatan yangDitujukan Terhadap Hak Milik dan lain-lainHak yang Timbul dari Hak Milik, TARSITO, Bandung.

\footnotetext{
${ }^{20}$ Manan, A. (2006). Aspek-Aspek Pengubah Hukum, Kencana, Jakarta. h. 97

${ }^{21}$ Sunarso, S. (2009). Hukum Informasi dan Transaksi Elektronik, PT Rineka Cipta,Jakarta, hlm. 39.
} 
Manan, A. (2006). Aspek-Aspek Pengubah Hukum, Kencana, Jakarta

Sunarso, S. (2009). Hukum Informasi dan Transaksi Elektronik, PT Rineka Cipta, Jakarta.

Yosep, T. (2016). Advokat dan Penegakan Hukum, GENTA Press, Yogyakarta.

\section{Peraturan Perundang-Undangan}

Undang-Undang Nomor 11 Tahun 2008 tentang Informasi dan Transaksi Elektronik.

Undang-Undang Nomor 19 Tahun 2016 tentang Informasi dan Transaksi Elektronik.

\section{Jurnal}

Juditha, C. (2018). Interaksi Komunikasi Hoax di Media Sosial serta Antisipasinya. Jurnal Pekomnas, 3(1), h. 31-44.

Pawestri, A. Y. (2019). Citra Hukum dan Demokrasi dalam Sistem Penegakkan Hukum Lingkungan Indonesia. Jurnal Ilmiah Ilmu Hukum, 17 (2), h. 98.

Situmorang, F.S. dkk. (2017), Tinjauan Yuridis Terhadap Ketentuan Pasal 28ayat 2 UU informasi dan tekhnologi, Kertha Wicara, 6(5), h. 12.

Supriyono \& Irawan, A. D. (2020). Semangat Kebangkitan Nasional Untuk MenghadapiCovid-19 Dalam Konteks Pancasila dan Konstitusi. Jurnal Pendidikan Sosial Keberagaman, 7(2).

Zakarya, I. B. dkk. (2014), Kewenangan Jaksa PenuntutUmum dalam Penahanan Tersangka Tanpa Alasan yang Jelas. Other thesis, Universitas Muhammadiyah Surabaya.

\section{Online/World Wide Web:}

Fahriza, R. (2018), Stagnansi Penegakan Hukum di Indonesia Menjadi Alarm, https://m.antaranews.com

Firmansyah, T. Polisi Tangkap Penyebar Hoaks Vaksin [Berita online REPUBLIKA.co.id, Kamis 28 Januari 2021 20:20 WIB] tersedia di situs: https://www.google.com/amp/s/m.republika.co.id/amp/qnnbqj377

Halim, D. 6 Bulan Pandemi Covid-19: Hoaks dan Teori Konspirasi yang Memperparah Penanganan [Berita Online Kompas.com Sabtu, 5 Sep 2020 09.09 WIB], tersedia di situs: https://www.google.com/amp/s/amp.kompas.com/nasional/read/2020/09/05/090 
90921/6-bulan-pandemi-covid-19-hoaks-dan-teori-konspirasi-yangmemperparah

Sumadi, H. (2016). Kendala dalam menanggulangi tindak pidana penipuan transaksi elektronik di Indonesia, https://download.portalgaruda.org/article

Tawakal, I. Kenali Perbedaan Misinformasi, Disinformasi, Malinformasi dalam Berita Hoaks yang Sering Gegerkan Masyarakat [Berita Online depok.pikiran- rakyat.com 6 Feb 2020 10:33 WIB], tersedia di situs: https://www.google.com/amp/s/depok.pikiranrakyat.com/pendidikan/amp/pr- 09337507/kenali-perbedaan-misinformasidisinformasi-malinformasi-dalam-berita- hoaks-yang-sering-gegerkan$\underline{\text { masyarakat }}$

Wahid, A. B. "Gencarkan Patroli Siber, Polri tangani 41 Hoax soal Corona", tersedia di situs: https://news.detik.com/berita/d-4949856/gencarkan-patrolisiber- polri-tangani-41-hoax-soal-corona 